\title{
Energy efficiency using Distributed Generation; Cafeteria of Engineer Faculty
} Campeche, Mexico

\section{Eficiencia energética con Generación Distribuida Fotovoltaica (GD-PV); Cafetería de la Facultad de Ingeniería de la Universidad Autónoma de Campeche, México}

CHAN-GONZALEZ, Jorge J $\dagger^{*}$, SARAVIA-PÉREZ, Isaac A., LEZAMA-ZÁRRAGA, Francisco and SHIH, Meng Yen

Universidad Autónoma De Campeche, Campus V, Predio s/n por Av. Humberto Lanz Cárdenas y Unidad Habitacional Ecológica Ambiental, Col. Ex-Hacienda Kalá, CP 24085, San Francisco de Campeche, Cam., México.

ID $1^{\text {st }}$ Author: Jorge J., Chan-Gonzalez / ORC ID: 0000-0002-8638-1646, CVU CONACYT ID: 89415

ID $1^{\text {st }}$ Co-author: Isaac A., Saravia-Pérez / ORC ID: 0000-0003-1839-8013

ID $2^{\text {nd }}$ Co-author: Francisco, Lezama-Zárraga / ORC ID: 0000-0001-7475-6458, CVU CONACYT ID: 408617

ID $3^{\text {rd }}$ Co-author: Meng Yen, Shih / ORC ID: 0000-0003-3397-7881, Research ID Thomson: U-1229-2018, CVU CONACYT ID: 205493

DOI: $10.35429 / J R D .2021 .20 .7 .1 .12$

Received July 02, 2021; Accepted October 29, 2021

Abstract

In the present work, an integral design of the cafeteria located at Faculty of Engineering of Autonomous University of Campeche is carried out. Four scenarios of Photo Voltaic (PV) generation have been studied. A 14 PV modules arrangement of 440 each, with azimuthal angle of $180^{\circ}$ and a slope angle of $15^{\circ}$; the other is similar to the previous, but the slope angle was $19.85^{\circ}$. The following was a $24 \mathrm{PV}$ modules arrangement of 440, with an azimuthal angle of $218^{\circ}$ and a slope angle of $15^{\circ}$. The last arrangement consists of $24 \mathrm{PV}$ modules arrangement of 440, with azimuthal angle of $218^{\circ}$ and a slope angle of $19.85^{\circ}$. Where all of them are associated with the economic aspect to obtain greater efficiency of the plant with minimum recovery time. The free software System Advisor Model (SAM) developed by the National Renewable Energy Laboratory (NREL) has been employed. Complete seasonal analysis has also been performed considering Gran Demanda Media Ordinaria en México (GDMO de CFE in Mexico) within the period January 2020 to March 2021. The best results are energy generation $17,570 \mathrm{kWh}$. Capacity factor $19 \%$. Energy performance $1,671 \mathrm{kWh} / \mathrm{kW}$. Performance relation 0.74. Leveled cost $5.39 \phi / \mathrm{kWh}$. And return on investment in 0.6 years. The GD-PV plant prevents the emission into the atmosphere of $778.85 \mathrm{~kg}$ of $\mathrm{CO}_{2}$ equivalent.

Distributed generation, Energy efficiency, Grid-connected photovoltaic systems, Photovoltaic distributed generation

\begin{abstract}
Resumen
En el presente trabajo se realizó un diseño integral de eficiencia energética en la cafetería de la Facultad de Ingeniería de la Universidad Autónoma de Campeche, México. Se analizaron 4 esquemas diferentes: un arreglo fotovoltaico de 14 módulos de 440 cada uno, ángulo azimutal de $180^{\circ}$ y ángulo de inclinación de $15^{\circ}$; el otro fue similar al anterior pero con ángulo de inclinación de $19.85^{\circ}$. El siguiente fue de 24 módulos de 440, ángulo azimutal de $218^{\circ}$ y ángulo de inclinación de $15^{\circ}$; por último arreglo fotovoltaico de 24 módulos de 440, ángulo azimutal de $218^{\circ}$ y ángulo de inclinación de 19.85 , asociados al aspecto económico, para obtener la mayor eficiencia de planta en el menor tiempo de recuperación. Se empleó el software libre System Advisor Model (SAM) desarrollado por el National Renewable Energy Laboratory (NREL). Contempló las tarifas económicas con análisis temporal completo, horario en tarifa Gran Demanda Media Ordinaria en México (GDMO de CFE en México). Los datos de facturación de la Comisión Federal de Electricidad fueron de enero de 2020 a marzo de 2021. Los mejores resultados son: Generación de energía, 17,570 kWh. Factor de capacidad 19\%. Rendimiento energético 1,671 $\mathrm{kWh} / \mathrm{kW}$. Relación de desempeño 0.74. Costo nivelado 5.39 $\phi / \mathrm{kWh}$. Retorno de inversión 0.6 años. La planta GD-PV previene la emisión a la atmósfera de $778.85 \mathrm{~kg}$ of $\mathrm{CO}_{2}$ equivalente.
\end{abstract}

Generación distribuida, Eficiencia energética, Sistemas fotovoltaicos interconectados a red, Generación distribuida fotovoltaica

Citation: CHAN-GONZALEZ, Jorge J., SARAVIA-PÉREZ, Isaac A., LEZAMA-ZÁRRAGA, Francisco and SHIH, Meng Yen. Energy efficiency using Distributed Generation; Cafeteria of Engineer Faculty Campeche, Mexico. Journal of Research and Development. 2021. 7-20: 1-12

$\dagger$ Researcher contributing as first author. 


\section{Introduction}

The Faculty of Engineering of the Universidad Autónoma de Campeche currently has an outdoor cafeteria. It currently has a transparent polycarbonate roof. However, the accrediting institutions of the Bachelor's degree programs have made the recommendation that the Faculty should have a more adequate cafeteria with, among other things, an air conditioning system. A multidisciplinary cabinet projected the construction of a new cafeteria that has all the amenities for a healthy recreation and relaxation of students, teachers and administrative staff. In this work an integral design was made to guarantee energy efficiency in the cafeteria of the Faculty of Engineering of the Autonomous University of Campeche, Mexico.

The architectural project consists of designing an enclosed space with capacity for approximately 80 people (diners and dependents). For these infrastructure dimensions, the number of people contemplated and that the building was planned with few windows that are exposed to solar radiation. It is considered to have a total heat gain of approximately $16 \mathrm{~kW}$-thermal (4.5 TR, 54,000 BTU/h). So with 2 units of $10.6 \mathrm{~kW}$-thermal (3 TR, 36,000 BTU/h, commercial capacities) we will have a total of $21.2 \mathrm{~kW}$-thermal (6 TR, $72,000 \mathrm{BTU} / \mathrm{h}$ ) sufficient to remove the total heat from the cooler.

During the engineering project development stage, it is very necessary to visualize different possible scenarios in the installation of a photovoltaic generating plant, such as the optimal inclination, the minimum height of the modules with respect to the surface, among others, and in turn all of them invariably associated to the economic aspect, in such a way that the highest plant efficiency is obtained in the shortest recovery time. To plan all these scenarios is an arduous task that requires the help of a computer program. In this sense, we used the System Advisor Model (SAM) software developed by the National Renewable Energy Laboratory (NREL) of the United States of America, for two important reasons: it is free and contemplates the economic rates that allow us to analyze the optimal performance of the plant, as well as its return on investment. The SAM program allowed the complete temporal, hourly analysis of the Gran Demanda Media Ordinaria en México (GDMO of CFE in Mexico) tariff during the 8760 hours of the year.
The tariff part is the most complex part of the programming, but it allows to do it; other similar programs do not have this analysis capacity. It allowed a finer analysis by relating the energy yield equations to an economic analysis (cash flow, net present value, payback time, cost benefit and internal rate of return). Distributed Generation (DG) from renewable energies has increased worldwide as an efficient tool to lower electric energy costs, since it reduces transmission costs, as well as increases the electric efficiency of the Load Center where it is installed. It represents a direct help to companies and governmental institutions to be more competitive on the one hand and to reduce their operating expenses on the other hand; this favors economic development.

Distributed Photovoltaic Generation (DG-PV) has become one of the main ways to generate electricity with renewable sources (Pinargote, D. F. G., et al 2021). In addition to delivering electric power directly to the grid, it provides other added values such as mitigating greenhouse gases and performing as a thermal barrier on the roofs of the buildings that house them. In other words, they prevent solar radiation gain in buildings, a fact that is especially relevant in hot-humid climates such as that of the state of Campeche, Mexico. By taking advantage of DG-PV in an educational institution in the state of Campeche where the reduction of energy consumption for air conditioning is imperative, and one of the main challenges to overcome is to curb heat gains from solar radiation, it becomes very attractive.

These actions generate net economic benefits to justify the payment of the initial investment. Distributed Generation (DG) is defined as: "the generation of electric energy that is interconnected to a distribution circuit containing a high concentration of Load Centers (CRE 2017)", according to the Electricity Industry Law and the Interconnection Manual of DG Plants with capacity less than 0.5 MW. DG includes that which is performed by an exempt generator, in other words, the owner of one or more power plants with capacity less than 0.5 MW that do not require a permit to generate electric power. DG can be located in the facilities of Load Centers or outside them (SENER, 2016). It is estimated that the world distributed solar PV, will establish itself at more than twice its capacity in the next lustrum. 
It accounts for almost half of the total solar PV expansion. DG-PV installations in educational and government institutions, residential homes, commercial buildings and industry will bring major changes to electrical systems. The accelerating expansion in the ability of consumers to generate their own electricity represents a niche opportunity for service providers.

\section{Justification}

Electricity consumption for air conditioning in educational institutions in Campeche and in general with hot humid climates represents one of the highest costs during operation. During the last five years, electricity consumption at the Universidad Autónoma de Campeche represents $60 \%$ of the total consumed each month.

In Mexico, in recent years, the contracting of DG-PV has increased considerably. Up to 2019, 35,661 new PV-GD contracts were signed, which is equivalent to just over 233 MW new installed in Mexico; this represents an average annual growth rate of approximately $20 \%$.

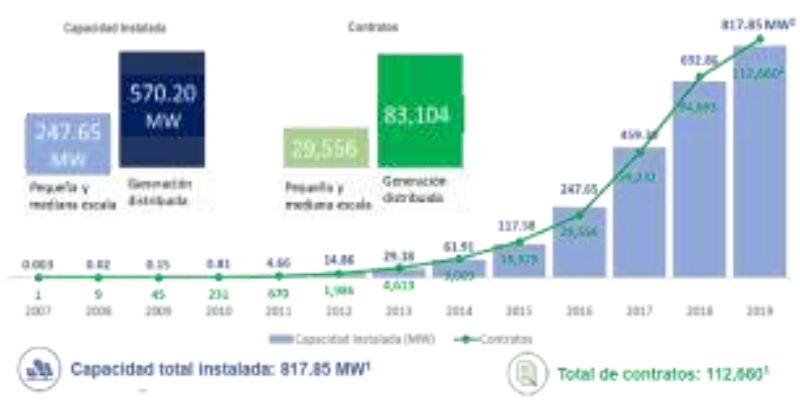

Figure 1 Evolution of contracts and installed capacity in Mexico

Monitor of commercial information and price index of Distributed Solar Generation in Mexico, March 2019

(Monitor of commercial information and price index of Distributed Solar Generation in Mexico, 2020). Figure 1.

Taking as a reference the Monitor of commercial information and price index of Distributed Solar Generation in Mexico, March 2020, from 2017 to the first semester of 2019, we present the regions that installed the largest amounts of DG-PV where it is very clear that the states of the Mexican Republic with the largest accumulated installed capacity are Jalisco, North Gulf, North, Bajio and South Valley of Mexico, Figure 2.
We also observe from Figure 2 that the state of Campeche has a very small accumulated installed capacity, less than $5 \mathrm{MW}$. However, the state of Campeche has a good solar radiation resource, with irradiation ranging from 4.5 to 6 $\mathrm{kWh} / \mathrm{m}^{2}$ per day. Data provided by NREL.

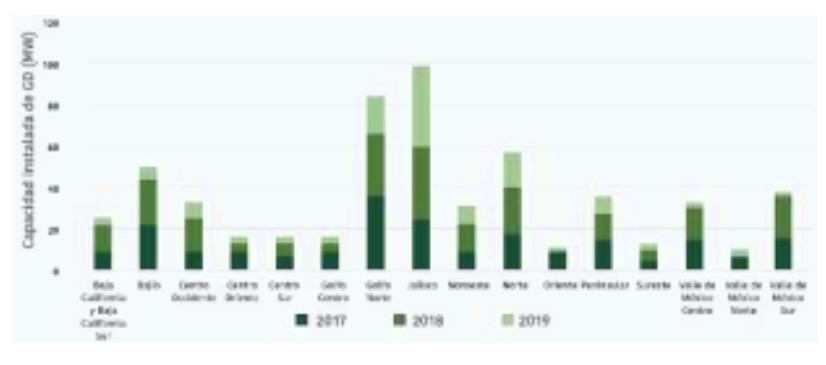

Figure 2 Evolution of DG-PV capacity in Mexico by region of the country

Commercial information monitor and price index for Distributed Solar Generation in Mexico, March 2021

The conditions of good irradiance in the state of Campeche as well as the energy needs and a small accumulated installed capacity, leads us to the conclusion that there is a large niche of opportunities for the installation of Photovoltaic Distributed Generation Systems.

On the other hand, the state of Campeche has a humid-warm climate; therefore, it is very necessary to use large amounts of electrical energy for high, medium and low temperature refrigeration processes. In a study conducted by the Autonomous University of Campeche to the Secretary of Economic Development of the state of Campeche in 2020 (Victor-Lanz et al), indicates that at least $60 \%$ of electricity consumption in small and medium industries, homes, schools and universities, is due to cooling processes in any of its forms. Particularly the state's educational institutions spend large amounts of their annual budget for the payment of electricity for air conditioning.

For example the Faculty of Engineering of the Autonomous University of Campeche, during 2019 had an average monthly billing of 150,000 Mexican pesos (approximately 7,500 U.S. dollars). Data taken from CFE receipts). In that sense, a circumstance that is very relevant is to avoid excessive heat gain from solar radiation on roofs and walls. It is known (Victorio Santiago Díaz et al, 2005) that approximately 50 to $60 \%$ of the total gain in buildings is due to solar radiation from roofs and walls. 
In air conditioning engineering applications, an average solar gain per roof of $550 \mathrm{w} / \mathrm{m}^{2}$ can be considered as the energy captured in a square meter of surface, in a horizontal position with the sun at the zenith and considering a clean atmosphere with a low degree of turbidity.

We conclude that GD-PV systems have an added value in hot-humid climates, and installed on roofs; they operate as thermal barriers that absorb direct solar radiation, avoiding excessive heat gains from solar radiation in buildings. As a direct consequence of the above, less electrical energy is required for air conditioning processes. In this way, energy efficiency is promoted.

With regard to energy efficiency, according to Deutsche Gesellschaft fur Internationale Zusammenarbeit (GIZ-2014) in its guide of good practices for energy saving and efficient use of energy, it is defined as: obtaining the same energy goods and services, but with much less energy, with the same or higher quality of life, with less pollution, at a lower price than at present, extending the life of resources and with less conflict.

\section{Objective}

To demonstrate that by implementing Distributed Generation with photovoltaic systems (DG-PV) together with aspects of bioclimatic architecture, energy efficiency is achieved in the cafeteria of the Faculty of Engineering of the Autonomous University of Campeche.

\section{Hypothesis}

By implementing a GD-PV plant, with its most optimal configuration, in the cafeteria of the Faculty of Engineering of the Autonomous University of Campeche, energy efficiency and reduction of its production costs are achieved; as well as avoiding the emission of $\mathrm{CO} 2$ equivalent to the atmosphere.

\section{Problem Statement}

It is desired to reduce the energy consumption of the cafeteria located in the Faculty of Engineering of the Autonomous University of Campeche, in the state of Campeche.
The state of Campeche is geographically located in the Yucatan Peninsula between parallels $17^{\circ} 49^{\prime}$ and $20^{\circ} 51^{\prime}$ north latitude; and between meridians $89^{\circ} 06^{\prime}$ and $92^{\circ} 27^{\prime}$ west; air conditioning processes demand high energy values to be carried out. The environmental conditions at the site are important adverse factors during this process.

The location of the cafeteria is in the Faculty of Engineering of the Universidad Autónoma de Campeche. It is geographically right at $19^{\circ} .84^{\prime} 58^{\prime \prime}$ north latitude, $-90^{\circ} .47^{\prime} 74^{\prime \prime}$ longitude (west), less than 1000 meters from the coast with an average temperature of $31 \pm 0.1^{\circ} \mathrm{C}$ and a relative humidity of $75 \pm 1 \%$, also average (INEGI, 2015), at 50 meters with respect to sea level. The architectural project consists of design an enclosed space with capacity for approximately 80 people (diners and dependents).

For these infrastructure dimensions, the number of people contemplated and that the building was planned with few windows that are exposed to solar radiation. It is considered to have a total heat gain of approximately 16 $\mathrm{kW}_{\text {thermal }}(4.5 \mathrm{TR}, 54,000 \mathrm{BTU} / \mathrm{h})$. So with 2 units of $10.6 \mathrm{~kW}_{\text {thermal }}(3 \mathrm{TR}, 36,000 \mathrm{BTU} / \mathrm{h}$, commercial capacities) we will have a total of $21.2 \mathrm{~kW}_{\text {thermal }}(6 \mathrm{TR}, 72,000 \mathrm{BTU} / \mathrm{h})$ sufficient to remove the total heat from the cooler. The cafeteria has 2 cassette type air conditioning units, which allow a better distribution of the cold air conditioning, which have an elegant presentation, which are very quiet (53/51/48 $\mathrm{dB}(\mathrm{A})$ continuous ambient noise level should not exceed 68 decibels, measured at the worker's ear position through the use of a sound level meter). According to, 01-13-95 Mexican Official Standard NOM-081-ECOL-1994, which establishes the maximum permissible noise emission limits for fixed sources and their measurement method.

Two 16 SEER high energy efficiency mini-split condensing units are also installed for this project. Ceiling mounted, with ecological refrigerant R410a. It also has lighting and miscellaneous equipment. Given this situation of energy demand, the possibility of installing a Photovoltaic Distributed Generation plant (GDPV) was considered. 


\section{Description of the Photovoltaic Distributed Generation System (GD-PV)}

This is an electric power generating plant produced with photovoltaic modules. It is installed on a flat roof of $89.10 \mathrm{~m}^{2}$. The first photovoltaic array (AFV) has two strings of seven modules, each of $440 \mathrm{Wp}$. This results in a total of 14 photovoltaic modules connected in series (Canadian brand), a total installation of $7.56 \mathrm{kWp}$ installed. It has an anti-island voltage inverter for interconnection to the grid of the brand and model Fronius Symo of $8 \mathrm{kWp}$ figure 3. Each photovoltaic module has an area of $2 \mathrm{~m}^{2}$. Figure 4 shows the one-line diagram of the system.

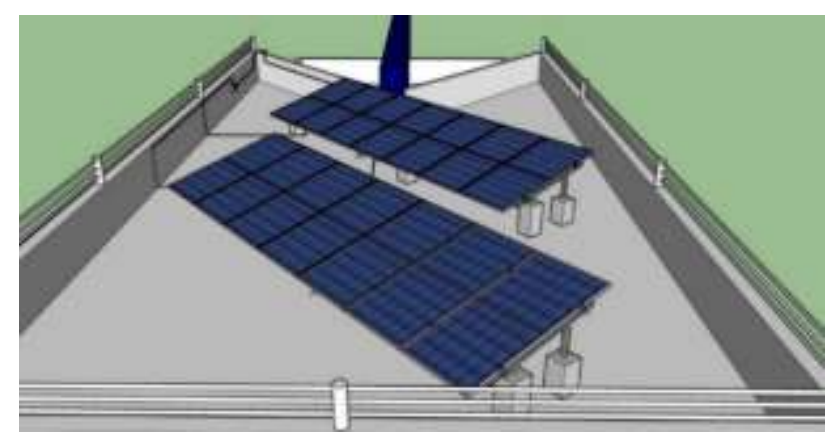

Figure 3 The photovoltaic array (AFV) has a total of 14 photovoltaic modules connected in series (Canadian brand) and an anti-islanding voltage inverter for interconnection to the grid of the Fronius Symo $5 \mathrm{kWp}$ brand and model

Own Elaboration.

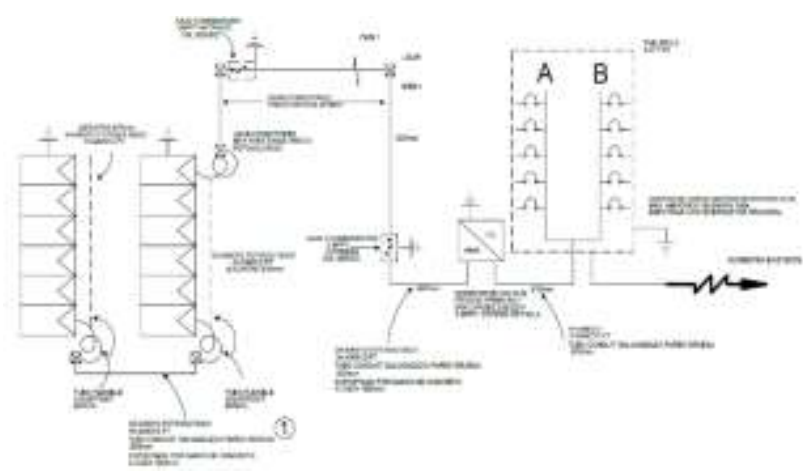

Figure 4 One-line diagram of the Distributed Photovoltaic Generation plant. It consists of 14 modules with a total installed capacity of $5.18 \mathrm{kWp}$

Own Elaboration

The next proposed photovoltaic array was to place 24 modules of 440 each, with an azimuthal angle of $218^{\circ}$, aligning them parallel to the side walls of the building and an inclination angle of $15^{\circ}$, a total installation of $10.56 \mathrm{kWp}$. It has an anti-islanding voltage inverter for interconnection to the grid of the brand and model Fronius Symo of $10 \mathrm{kWp}$.

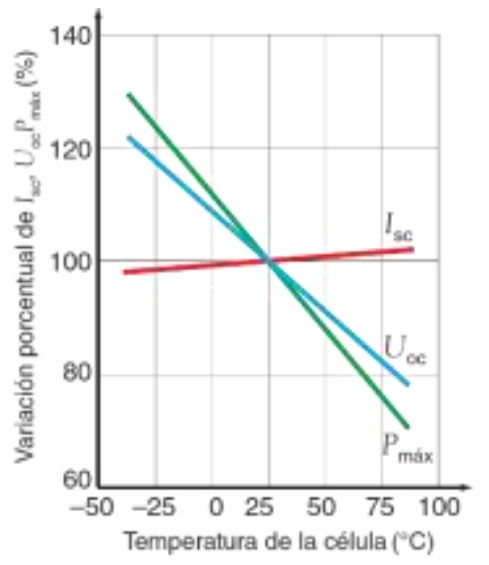

Figure 5 Percentage variation of open circuit voltage, short circuit current and maximum power of a photovoltaic module with respect to temperature

Castejón 2012

The PV installation was designed with an inclination of 15 degrees with respect to the horizontal plane to optimize the PV performance with respect to mechanical stresses (RayenariD.C. et al., 2015); hence each module shades an area of $1.93 \mathrm{~m} 2$. The total PV installation produces a shaded roof area of about $27 \mathrm{~m} 2$. The photovoltaic plant is fully oriented to the south, its azimuthal declination is correct. The photovoltaic modules are placed at a height of $0.60 \mathrm{~m}$ with respect to the roof, in order to favor air circulation under them, thus ensuring that they do not overheat and considerably increase their production efficiency (Agustín Castejón2012, Cruz Arellano, M. \& Castillo Téllez, M. 2021). Figure 5, recalling that as the modules heat up, taking as a reference the value of $25^{\circ} \mathrm{C}$, their open circuit voltage (Voc) decreases linearly and with a steep slope. Power in turn is intimately influenced by Voc. In such a way that if the temperature is increased to values higher than $75^{\circ} \mathrm{C}$, more than $20 \%$ of the nominal power is lost.

Similarly Rayenari D. C. et al, (2015) recommend for higher photovoltaic efficiency in the months of March to August, the tilt should be readjusted to 10 or 5 degrees. Up to $5 \%$ efficiency gain is possible. In addition, stagnation zones are avoided due to no wind circulation Potter et al (2011).

\section{Mathematical modeling of heat gain through the freezer roof}

According to Victor Lanz G. et al (2018), in hot humid climates heat gain in building roofs represents $40 \%$ and another $10 \%$ by walls facing the direct solar radiation received by a building throughout the day. 
Therefore, it is very important to quantify the heat gain from roofs. The following equations are presented to quantify roof heat gains as a combined effect of conduction, convection and radiation (Céngel et al-2012).

$$
\begin{gathered}
\begin{array}{c}
\dot{Q}=\dot{Q}_{\text {habi-techo,conv }+ \text { rad }}=\dot{Q}_{\text {cond }, \text { techo }} \\
=\dot{Q}_{\text {techo-amb,cond }+ \text { rad }}
\end{array} \\
\dot{Q}_{\text {habi-techo,conv }+ \text { rad }}= \\
h_{i} A\left(T_{\text {habi }}-T_{s, \text { int }}\right)+\varepsilon A \sigma\left(T_{\text {habit }}^{4}-T_{s, \text { int }}^{4}\right) \\
\dot{Q}_{\text {cond,techo }}=k A \frac{T_{s, \text { int }}-T_{s, \text { ext }}}{L} \\
\dot{Q}_{\text {techo-alrededor,cond }+ \text { rad }}= \\
h_{o} A\left(T_{s, \text { ext }}-T_{\text {amb }}\right)+\varepsilon A \sigma\left(T_{s, \text { ext }}^{4}-T_{\text {amb }}^{4}\right) \\
-\alpha \dot{q}_{\text {solar }}
\end{gathered}
$$

Where $\dot{Q}$ is the total heat flux, k thermal conductivity, $\alpha$ absorptivity, $h=k W / m^{2} \quad{ }^{o} \mathrm{C}$ convective heat transfer coefficient, $\sigma$ the Steffan-Boltzman constant, A heat transfer area, $\dot{q}_{\text {solar }}$ solar radiation and $\mathrm{T}$ temperature. It is estimated that, each square meter of roof receives a radiation of $550 \mathrm{w} / \mathrm{m}^{2} \mathrm{x}$ day, and there are 27 and $46.32 \mathrm{~m} 2$ of area shaded by the PV plant for the cases of 14 and 24 modules respectively. It can then be estimated that a daily roof heat gain of approximately $14.85 \mathrm{~kW}$ is avoided for the 14-module case and $25.48 \mathrm{~kW}$ for the 24-module case. As a reference, mini split air conditioners of one ton of refrigeration have a thermal capacity to remove heat of $3.54 \mathrm{kWh}$. The shaded area represents approximately $30 \%$ of the total roof for the case of 14 modules and $51 \%$ when we have 24 modules.

\section{Bioclimatic aspects of energy efficiency in the cafeteria}

Another aspect considered to increase the energy efficiency of the cafeteria was to place green roofs and walls in the areas with the highest incidence of solar radiation. The proposal for green roofs and walls was made with vegetation native to the Yucatan Peninsula that can withstand the climatic conditions of the region.

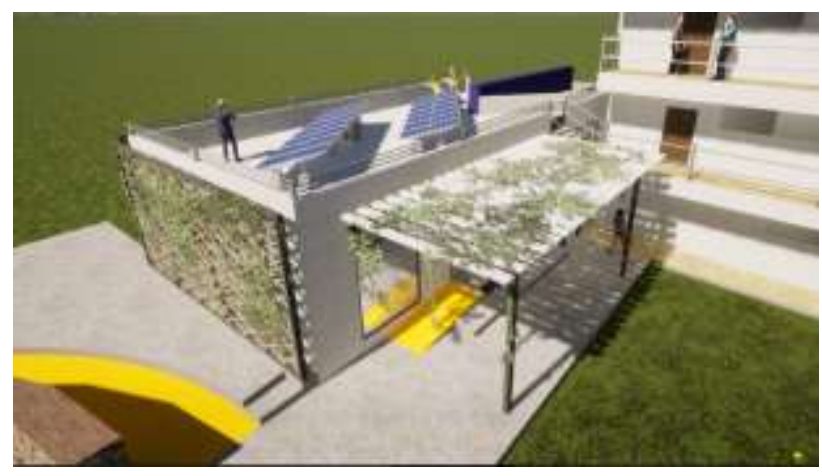

Figure 6 Overall view of the cafeteria with the proposed $\mathrm{SFV}$, roofs and green walls Own Elaboration

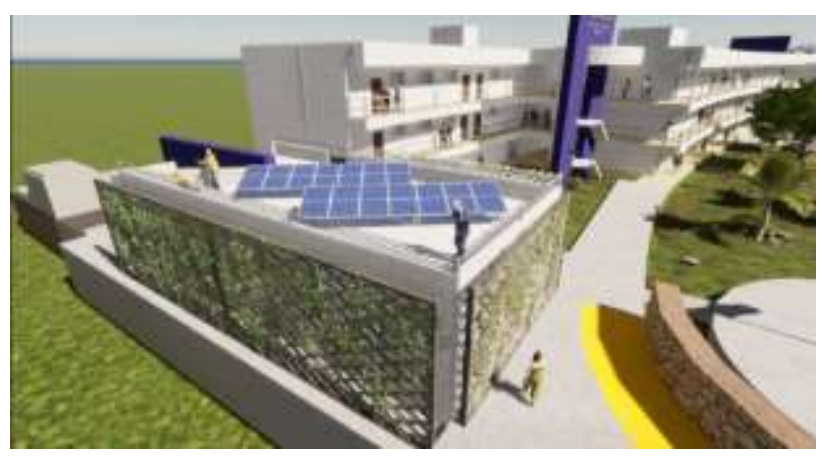

Figure 7 View of the rear wall of the cafeteria with the SFV proposals and green wall

Own Elaboration

\section{Proposed methodology for the analysis of photovoltaic electric energy production.}

In this work we used the free software called System Advisor Model (SAM) created by the National Renewable Energy Laboratory (NREL) of the United States of America. With this program we evaluated the energy capacity of several photovoltaic configurations to compare them and decide which one is the most optimal for installation.

During the engineering project development stage, it is very necessary to visualize different possible scenarios in the installation of a photovoltaic generating plant, such as the optimal inclination, the minimum height of the modules with respect to the surface, among others, and in turn all of them invariably associated to the economic aspect, in such a way that the highest plant efficiency is obtained in the shortest recovery time. To plan all these scenarios is an arduous task; this task is easier with the help of a computer program. In this sense, we use the SAM software for two important reasons: it is free and it contemplates economic rates. 
This allows us to analyze the optimal performance of the plant, as well as its return on investment. The SAM program allowed the complete temporal analysis of the Great Ordinary Mean Demand in Mexico (GDMO of CFE in Mexico) during the 8760 hours of the year. The tariff part is the most complex part of the programming, but it allows to do it; other similar programs do not have this analysis capacity. It allowed a more accurate analysis by relating the energy yield equations to an economic analysis (cash flow, net present value, payback time, cost benefit and internal rate of return). Four different schemes were analyzed, firstly, it was a photovoltaic array of 14 modules of 440 each, with an optimal azimuthal angle (Castejón \& Santamaría, 2010) of $180^{\circ}$ (i.e. aligned to the true north-south axis) and a tilt angle of $15^{\circ}$ (Rayenari-D.C. et al., 2015), the other was similar to the previous one but the tilt angle was $19.85^{\circ}$ equivalent to the latitude of Campeche.

The next was to place the PV array of 24 modules of 440 each, with an azimuthal angle of $218^{\circ}$, aligning them parallel to the side walls of the building and a tilt angle of $15^{\circ}$ and finally the PV array of 24 modules of 440 each, azimuthal angle of $218^{\circ}$ and tilt angle of $19.85^{\circ}$. The program was fed with the billing data issued by the Federal Electricity Commission (CFE), in GDMO tariff, for the period from January 2020 to March 2021. It corresponds to the consumption of the Faculty of Engineering during that period, Table 1. Costs are expressed in U.S. dollars.

\begin{tabular}{|l|r|}
\multicolumn{1}{|c|}{ Billing month } & $\begin{array}{r}\text { Total consumption } \\
\text { (kwh) }\end{array}$ \\
\hline January 2020 & 21,238 \\
\hline February 2020 & 22,803 \\
\hline March 2020 & 30,881 \\
\hline April 2020 & 28,791 \\
\hline May 2020 & 9,469 \\
\hline June 2020 & 10,752 \\
\hline July 2020 & 10,124 \\
\hline August 2020 & 10,686 \\
\hline September 2020 & 10,938 \\
\hline October 2020 & 14,400 \\
\hline November 2020 & 15,788 \\
\hline December 2020 & 15,996 \\
\hline January 2021 & 14,418 \\
\hline February 2021 & 15.441 \\
\hline March 2021 & 13.953 \\
\hline
\end{tabular}

Table 1 Details of the energy consumption used in the SAM Program to make the economic estimates. Taken from CFE receipts

Own Elaboration

\begin{tabular}{|l|r|r|}
\hline \multicolumn{1}{|c}{ Two subarrays: } & \multicolumn{1}{c|}{ 1 } \\
\hline Strings & 1 & 1 \\
\hline Modules per string & 7 & 7 \\
\hline String Voc (DC V) & 340.90 & 340.90 \\
\hline Tilt (deg from horizontal) & 15.00 & 15.00 \\
\hline Azimuth (deg E of N) & 180 & 180 \\
\hline Tracking & no & no \\
\hline Backtracking & - & - \\
\hline Self shading & no & no \\
\hline Rotation limit (deg) & - & - \\
\hline Shading & no & no \\
\hline Snow & no & no \\
\hline Soiling & yes & yes \\
\hline DC losses (\%) & 4.44 & 4.44 \\
\hline
\end{tabular}

Table 2 Details of the photovoltaic installation with 14 modules of 440 each, azimuth angle of $180^{\circ}$ and tilt angle of $15^{\circ}$. SAM program.

The first two options considered were because they were placed at the optimum azimuthal angle. However, arranged in this way and for space reasons, only 14 modules fit. The last two options allow a greater number of modules to be placed, although a small percentage of efficiency is lost $(5 \%)$.

\section{Analysis of the information and results obtained}

After the four scenarios were proposed and the program was fed with the necessary data, we proceeded to run the program with each of them. The results obtained are presented in the following tables.

\begin{tabular}{|l|r|}
\hline \multicolumn{1}{|c|}{ Metrics } & \multicolumn{1}{c|}{ Values } \\
\hline Annual energy (year 1) & $10.451 \mathrm{kWh}$ \\
\hline Capacity factor (year 1) & $\begin{array}{r}1.696 \\
\mathrm{kWh} / \mathrm{kW}\end{array}$ \\
\hline Energy yield (year 1) & 0.77 \\
\hline Performance ratio (year 1) & $5.40 \not / \mathrm{kWh}$ \\
\hline COE level (nominal) & $\$ 314,513$ \\
\hline $\begin{array}{l}\text { Electricity payment without the system } \\
\text { (year 1) }\end{array}$ & $\$ 303,184$ \\
\hline $\begin{array}{l}\text { Electricity payment with the system (year } \\
\text { 1) }\end{array}$ & $\$ 11,329$ \\
\hline Net savings with system (year 1) & $\$ 202,761$ \\
\hline Net present value & 0.6 años \\
\hline Simple return period & $\$ 8,256$ \\
\hline Net capital cost & \\
\hline
\end{tabular}

Table 3 Simulation results, PV installation with 14 modules of 440 each, azimuth angle of $180^{\circ}$ and tilt angle of $15^{\circ}$. SAM program. 


\begin{tabular}{|c|c|}
\hline Metrics & Values \\
\hline Annual energy (year 1) & $10.465 \mathrm{kWh}$ \\
\hline Capacity factor (year 1) & $19.40 \%$ \\
\hline Energy yield (year 1) & $\begin{array}{r}1.699 \mathrm{kWh} / \mathrm{k} \\
\mathrm{W}\end{array}$ \\
\hline Performance ratio (year 1) & 0.77 \\
\hline COE level (nominal) & $5,39 \phi / \mathrm{kWh}$ \\
\hline $\begin{array}{l}\text { Electricity payment without the system } \\
\text { (year 1) }\end{array}$ & $\$ 314,513$ \\
\hline $\begin{array}{l}\text { Electricity payment with the system (year } \\
\text { 1) }\end{array}$ & $\$ 303,156$ \\
\hline Net savings with system (year 1) & $\$ 11,357$ \\
\hline Net present value & $\$ 203,283$ \\
\hline Simple return period & 0.6 años \\
\hline Net capital cost & $\$ 8.256$ \\
\hline
\end{tabular}

Table 4 Simulation results, PV system with 14 modules of 440 each, azimuth angle of $180^{\circ}$ and tilt angle of $19.85^{\circ}$. SAM program.

\begin{tabular}{|l|r|}
\hline \multicolumn{1}{|c|}{ Metrics } & \multicolumn{1}{c|}{ Values } \\
\hline Annual energy (year 1) & $17.649 \mathrm{kWh}$ \\
\hline Capacity factor (year 1) & $19.10 \%$ \\
\hline Energy yield (year 1) & $1.671 \mathrm{kWh} / \mathrm{k}$ \\
\hline Performance ratio (year 1)
\end{tabular}

Table 5. Simulation results, PV system with 24 modules of 440 each, azimuth angle of $218^{\circ}$ and tilt angle of $15^{\circ}$. SAM program.

\begin{tabular}{|l|r|}
\hline \multicolumn{1}{|c|}{ Metrics } & \multicolumn{1}{c|}{ Values } \\
\hline Annual energy (year 1) & $17.570 \mathrm{kWh}$ \\
\hline Capacity factor (year 1) & $19.00 \%$ \\
\hline Energy yield (year 1) & $\begin{array}{r}1.664 \\
\mathrm{kWh} / \mathrm{kW}\end{array}$ \\
\hline Performance ratio (year 1) & 0.78 \\
\hline COE level (nominal) & $5,50 \phi / \mathrm{kWh}$ \\
\hline $\begin{array}{l}\text { Electricity payment without the system } \\
\text { (year 1) }\end{array}$ & $\$ 314,513$ \\
\hline $\begin{array}{l}\text { Electricity payment with the system } \\
\text { (year 1) }\end{array}$ & $\$ 295,467$ \\
\hline Net savings with system (year 1) & $\$ 19,046$ \\
\hline Net present value & $\$ 340,946$ \\
\hline Simple return period & $0.6 \mathrm{años}$ \\
\hline Net capital cost & $\$ 14,153$ \\
\hline
\end{tabular}

Table 6. Simulation results, PV installation with 24 modules of 440 each, azimuth angle of $218^{\circ}$ and inclination angle of $19.85^{\circ}$. SAM program.
Some of the results obtained in this section are specified.

Capacity factor (CF) is defined by NREL as:

$$
C F=\frac{\text { Annual energy production }\left[\frac{\mathrm{kWh}}{\text { year }}\right]}{\text { Installed capacity } x 24\left[\frac{\text { hours }}{\text { day }}\right] \times 365\left[\frac{\text { day }}{\text { year }}\right]}
$$

Energy yield is given by (Theristis et al., 2018) as the energy produced between each installed peak kilowatt.

The performance or performance ratio (performance ratio) is a magnitude, independent of the location, of the quality of a PV installation. It is a quality factor. It is expressed as a percentage and shows the ratio between the actual yield and the nominal yield of the PV system. It indicates what proportion of the energy is actually available after deduction of energy losses (thermal and cable losses) and own consumption for operation. The coefficient of performance provides information on the energy efficiency and reliability of the PV system.

The levelized cost (LCOE) is given by (Lai et al., 2019), equation 6.

$L C O E=\frac{\text { sum of whole life costs }}{\text { sum of the electrical energy produced in its entire useful life }}$

$L C O E=\frac{\sum_{t=1}^{n} \frac{I_{t}+M_{t}+F_{t}}{(1+r) t}}{\sum_{t=1}^{n} \frac{E_{t}}{(1+r)^{t}}}$

Where:

It: Investment expenses in year $t$.

$\mathrm{M}_{\mathrm{t}}$ : Operating and maintenance expenses in year $\mathrm{t}$.

$\mathrm{F}_{\mathrm{t}}$ : fuel expenses in year $\mathrm{t}$.

Et: electric power generated in year $t$.

r: discount ratio.

$\mathrm{n}$ : expected life time.

From the comparative tables, from 7 to 13, we observe that, of the proposed configurations, the one that produces the most annual energy is the one with 24 modules with an azimuth angle of $218^{\circ}$ and an inclination angle of $15^{\circ}$. That is, the installation is not at the angles considered optimal for this latitude. It is evident that, for this configuration, the fact of having 10 more modules with respect to the installation of 14 panels results in a higher energy production, but the paradigm of installing according to the established canons was broken, even with the understanding that we would have a $5 \%$ of total losses. Table 7. 


\begin{tabular}{|c|c|c|c|}
\hline $\begin{array}{c}14 \text { modules, } \\
\text { azimuth angle } \\
180 \text {, inclination } \\
15^{\circ} .\end{array}$ & $\begin{array}{c}14 \text { modules, } \\
\text { azimuth angle } \\
180 \text {, inclination } \\
19.8^{\circ} \text {. }\end{array}$ & $\begin{array}{c}24 \text { modules, } \\
\text { azimuth angle } \\
218, \text { inclination } \\
15^{\circ} .\end{array}$ & $\begin{array}{c}24 \text { modules, } \\
\text { azimuth angle } \\
218, \text { inclination } \\
19.8^{\circ} .\end{array}$ \\
\hline $10,451 \mathrm{kWh}$ & $10,465 \mathrm{kWh}$ & $17,649 \mathrm{kWh}$ & $17,570 \mathrm{kWh}$ \\
\hline
\end{tabular}

Table 7 Simulation results, PV installation. Energy generation. SAM program.

In Table 8, we observe that the configurations of 14 modules with an azimuthal angle of $180^{\circ}$ and inclination angles of 15 and $19.8^{\circ}$, are the ones with the highest capacity factor. This result is congruent if we consider the definition previously presented. In other words, we have higher energy production with less installed $\mathrm{kW}$.

\begin{tabular}{|c|c|c|c|}
\hline $\begin{array}{c}14 \text { modules, } \\
\text { azimuth angle } \\
180 \text {, inclination } \\
15^{\circ} .\end{array}$ & $\begin{array}{c}14 \text { modules, } \\
\text { azimuth angle } \\
180, \text { inclination } \\
19.8^{\circ} .\end{array}$ & $\begin{array}{c}24 \text { modules, } \\
\text { azimuth angle } \\
218, \text { inclination } \\
15^{\circ} \text {. }\end{array}$ & $\begin{array}{c}24 \text { modules, } \\
\text { azimuth angle } \\
218, \text { inclination } \\
19.8^{\circ} .\end{array}$ \\
\hline $19,40 \%$ & $19,40 \%$ & $19,10 \%$ & $19,00 \%$ \\
\hline
\end{tabular}

Table 8 Simulation results, PV installation. Capacity factor. SAM program.

From Table 9, we observe that the installation of 24 modules, azimuth angle of $218^{\circ}$ and tilt angle of $15^{\circ}$, is the one with the highest energy yield.

\begin{tabular}{|c|c|c|c|}
\hline $\begin{array}{c}14 \text { modules, } \\
\text { azimuth angle } \\
180 \text {, inclination } \\
15^{\circ} .\end{array}$ & $\begin{array}{c}14 \text { modules, } \\
\text { azimuth angle } \\
180 \text {, inclination } \\
19.8^{\circ} .\end{array}$ & $\begin{array}{c}24 \text { modules, } \\
\text { azimuth angle } \\
218, \text { inclination } \\
15^{\circ} \text {. }\end{array}$ & $\begin{array}{c}24 \text { modules, } \\
\text { azimuth angle } \\
218, \text { inclination } \\
19.8^{\circ} .\end{array}$ \\
\hline $1,696 \mathrm{kWh} / \mathrm{kW}$ & $1,699 \mathrm{kWh} / \mathrm{kW}$ & $1,671 \mathrm{kWh} / \mathrm{kW}$ & $1,664 \mathrm{kWh} / \mathrm{kW}$ \\
\hline
\end{tabular}

Table 9 Simulation results, PV system. Energy yield. SAM program.

In Table 10, we observe that the installation of 24 modules, azimuth angle of $218^{\circ}$ and tilt angle of $15^{\circ}$, is the one with the highest performance ratio factor. This indicates that this configuration has the lowest number of thermal and wiring losses and therefore the highest energy efficiency.

\begin{tabular}{|c|c|c|c|}
\hline $\begin{array}{c}14 \text { modules, } \\
\text { azimuth angle } \\
180 \text {, inclination } \\
15^{\circ} .\end{array}$ & $\begin{array}{c}14 \text { modules, } \\
\text { azimuth angle } \\
180 \text {, inclination } \\
19.8^{\circ} \text {. }\end{array}$ & $\begin{array}{c}24 \text { modules, } \\
\text { azimuth angle } \\
218, \text { inclination } \\
15^{\circ} .\end{array}$ & $\begin{array}{c}24 \text { modules, } \\
\text { azimuth angle } \\
218, \text { inclination } \\
19.8^{\circ} .\end{array}$ \\
\hline 0,77 & 0,77 & 0,78 & 0,78 \\
\hline
\end{tabular}

Table 10 Simulation results, PV installation. Performance ratio. SAM program.

On the other hand, in Table 11, we find that the installation of 14 modules with an azimuthal angle of $180^{\circ}$ and an inclination angle of $19.8^{\circ}$, is the one with the best levelized cost value. That is, it is the configuration that will offer the highest energy production at the lowest cost throughout its useful life.

ISSN 2444-4987

ECORFAN® All rights reserved

\begin{tabular}{|cccc|}
\hline $\begin{array}{c}14 \text { modules, } \\
\text { azimuth angle }\end{array}$ & $\begin{array}{c}14 \text { modules, } \\
\text { azimuth angle }\end{array}$ & $\begin{array}{c}24 \text { modules, } \\
\text { azimuth angle }\end{array}$ & $\begin{array}{c}24 \text { modules, } \\
\text { azimuth angle }\end{array}$ \\
180 , inclination & 180, inclination & 218, inclination & 218, inclination \\
$15^{\circ}$. & $19.8^{\circ}$. & $15^{\circ}$. & $19.8^{\circ}$. \\
\hline $5.40 \phi / \mathrm{kWh}$ & $5.39 \phi / \mathrm{kWh}$ & $5.48 \phi / \mathrm{kWh}$ & $5.50 \phi / \mathrm{kWh}$ \\
\hline
\end{tabular}

Table 11. Simulation results, $P V$ installation. Levelized cost. SAM program.

Tables 12 and 13 provide information on net money savings and payback periods and what can be seen is that the configuration of 24 modules, azimuth angle of $218^{\circ}$ and tilt angle of $15^{\circ}$, delivers the highest amount of money saved in one year of operation. And all configurations have the same payback time.

\begin{tabular}{|c|c|c|c|}
\hline $\begin{array}{c}14 \text { modules, } \\
\text { azimuth angle } \\
180, \text { inclination } \\
15^{\circ} .\end{array}$ & $\begin{array}{c}14 \text { modules, } \\
\text { azimuth angle } \\
180, \text { inclination }\end{array}$ & $\begin{array}{c}24 \text { modules, } \\
\text { azimuth angle } \\
218, \text { inclination }\end{array}$ & $\begin{array}{c}24 \text { modules, } \\
\text { azimuth angle } \\
218, \text { inclination }\end{array}$ \\
\hline$\$ 11,329$ & $\$ 11,357$. & $15^{\circ}$. & $19.8^{\circ}$. \\
\hline
\end{tabular}

Table 12 Simulation results, PV installation. Net savings. SAM program.

\begin{tabular}{|c|cc|c|}
\hline 14 modules, & 14 modules, & 24 modules, & 24 modules, \\
azimuth angle \\
180, inclination & azimuth angle & azimuth angle & azimuth angle \\
180, inclination & 218, inclination & 218, inclination \\
$15^{\circ}$. & $19.8^{\circ}$. & $15^{\circ}$. & $19.8^{\circ}$. \\
\hline 0.6 años & 0.6 años & 0.6 años & 0.6 años \\
\hline
\end{tabular}

Table 13 Simulation results, PV installation. Return period. SAM program.

\section{Energy produced by the DG-PV}

The energy produced by the DG-PV, E_prod in the 5.5 hours of solar radiation of a solar day (NREL, 2010), is given by equation 7.

$E_{\text {prod }}=W_{\text {peak }} \cdot h r_{\text {rad }} \cdot N o_{\text {módpv }}$

where $W_{\text {peak }}$ is the peak power of a PV module in Watts, $h r_{\text {rad }}$ is the hours of solar radiation in a day, and $N o_{m o ́} P_{V}$ represents the number of PV modules included in the DG-PV plant. From the above, the energy produced by the DG-PV, in both configurations, is given by:

$$
\begin{aligned}
& E_{\text {prod }}=0.440 \mathrm{~kW}(5.5 \mathrm{hr})(14 \mathrm{mód})= \\
& 33.88 \mathrm{kWh} / \text { day } \\
& E_{\text {prod }}=0.440 \mathrm{~kW}(5.5 \mathrm{hr})(24 \mathrm{mód})= \\
& 58.08 \mathrm{kWh} / \text { day }
\end{aligned}
$$




\section{Estimated $\mathrm{CO}_{2}$ avoided to be sent to the environment due to DG-PV}

Within an energy efficiency study, the amount of carbon dioxide $\left(\mathrm{CO}_{2}\right)$ emissions released into the environment due to electricity generation must be included. In Mexico, the Energy Regulatory Commission (CRE) and the Ministry of Environment and Natural Resources (SEMARNAT) annually estimate the National Electric System Emission Factor based on Article 12 of the Energy Transition Law Regulation (Chamber of Deputies, 2017). The last factor published in the Official Journal of the Federation was in 2017 being this of:

\section{$0.582 \mathrm{~kg}$ de $\mathrm{CO}_{2} / \mathrm{kWh}$}

In addition, an emission factor caused by the production of energy with photovoltaic modules has been considered; an analysis model called Global Emissions Model for Integrated Systems (GEMIS, 2018) was used in the calculations, which applies a factor of:

\section{$0.135 \mathrm{~kg}$ de $\mathrm{CO}_{2} / \mathrm{kWh}$}

And Reich, et al. (2007), invites to choose a value from a range of emissions between:

\subsection{0-0.317 kg de $\mathrm{CO}_{2} / \mathrm{kWh}$}

Empirically we choose the GEMIS factor for our calculations, because it is within Reich's range. During a billing month, the total energy consumed by the Faculty of Engineering and purchased from DG-PV is:

$E_{\text {cons }}=58.08 \frac{k W h}{\text { day }}(30$ days $)=1742.4 k W h$

Then, the $\mathrm{CO}_{2}$ emissions avoided to be sent to the $\epsilon_{\text {cons }} \epsilon$ _cons by the energy consumed through DG-PV is:

$\epsilon_{\text {cons }}=0.582 \frac{\mathrm{kg} \mathrm{CO}}{\mathrm{kWh}}(1742.4 \mathrm{kWh})=1014.07 \mathrm{kgCO}$

The $\mathrm{CO}_{2}$ emissions produced $\epsilon_{\text {prod }}$ caused by energy production with DG-PV are:

$\epsilon_{\text {prod }}=0.135 \frac{\mathrm{kgCO}}{\mathrm{kWh}}(1742.4 \mathrm{kWh})=235.22 \mathrm{~kg} \mathrm{CO}$

Finally, the net $\mathrm{CO}_{2}$ emissions $\epsilon \_$net avoided to be sent to the atmosphere is the difference between $\epsilon_{\text {cons }}$ y $\epsilon_{\text {prod }}$ : $\epsilon_{\text {net }}=\epsilon_{\text {cons }}-\epsilon_{\text {prod }}=1014.07 \mathrm{kgCO}-$ $235.22 \mathrm{kgCO}=778.85 \mathrm{kgCO}$

This is a significant figure, as it shows that $778.85 \mathrm{~kg}$ of $\mathrm{CO}_{2}$ are no longer being emitted into the environment, which is a significant contribution to the reduction of the carbon footprint.

\section{Conclusions}

This article presents an energy efficiency study of the Cafeteria of the Faculty of Engineering of the Autonomous University of Campeche with the proposal of a Photovoltaic Distributed Generation plant (GDF-PV) analyzing several proposed configurations with the help of the open program called System Advisor Model (SAM) developed by the National Renewable Energy Laboratory (NREL).

Four different schemes were analyzed: one PV array of 14 modules of 440 each, with an azimuthal angle of $180^{\circ}$ and a tilt angle of $15^{\circ}$, the other was similar to the previous one but the tilt angle was $19.85^{\circ}$ equivalent to the latitude of Campeche. The next two were arrays of 24 modules of 440 each, with azimuthal angles of $218^{\circ}$ and inclination angles of $15^{\circ}$ and $19.85^{\circ}$.

It is estimated that a daily roof heat gain of $14.85 \mathrm{~kW}$ is avoided in the case of 14 modules and $25.48 \mathrm{~kW}$ in the case of 24 modules. The shaded area represents approximately $30 \%$ of the total roof for 14 modules and $51 \%$ for 24 modules.

- $\quad$ The best annual energy generation of the DG-PV plants is obtained with a value of $17,649 \mathrm{kWh}$ in the configuration of 24 modules of $440 \mathrm{~W}$, with azimuth angle of $218^{\circ}$ and tilt angle of $15^{\circ}$. According to the simulations with the SAM program.

- $\quad$ The 24-module photovoltaic system, with an azimuth angle of $218^{\circ}$ and an inclination angle of $15^{\circ}$, has the highest energy yield with a value of 1,671 $\mathrm{kWh} / \mathrm{kW}$, understood as the energy produced for each kilowatt peak installed. 
- $\quad$ The 24-module photovoltaic plant, with azimuth angle of $218^{\circ}$ and tilt angle of $15^{\circ}$, is the one with the highest performance ratio factor, indicating that it has the lowest number of thermal and wiring losses and is therefore the one with the highest energy efficiency.

- All four DG-PV plant configurations have the same payback time of 0.6 years.

The best PV plant configuration was the 24-module configuration, with azimuth angle of $218^{\circ}$ and tilt angle of $15^{\circ}$, which has the highest number of favorable factors and is therefore the most energy efficient.

- $\quad$ The GD-PV plant avoids the emission of $778.85 \mathrm{~kg}$ of $\mathrm{CO} 2$ equivalent into the atmosphere.

To increase the energy efficiency of the cafeteria, green roofs and walls were installed in the areas with the highest incidence of solar radiation. The roofs and green walls were built with vegetation native to the Yucatan Peninsula to withstand the climatic conditions of the region.

\section{Acknowledgements}

The authors would like to thank the Universidad Autónoma de Campeche for the support and effort given during the development of this work to its researchers to disseminate the research topics in which they are involved.

\section{References}

Agustín Castejón, Germán Santamaría. (2012). Instalaciones solares fotovoltaicas. Editex. ISBN eBook 978-84-9771-749-6.

Cámara de Diputados. "Reglamento de la Ley de Transición Energética". Art. 12. Año 2017. Consultado en: http://www.diputados.gob.mx/LeyesBiblio/y/R eg_LTE_040517.pdfregle
Cruz Arellano, M. \& Castillo Tellez, M. (2021). Planteamiento de un modelo energético descriptivo aplicable a la instalación de sistemas solares fotovoltaicos interconectados a la red mediante generación distribuida: caso de estudio en Nuevo Laredo. Project, Design and Management, 3(1), 112-137. doi: 10.29314/pdm.v3i1.587

Delgado A. J. S. Villalón, O. R. \& Sánchez, M. M. L. (2020). Análisis tecno-económico de la operación en esquema de red inteligente $\mathrm{y}$ reserve energética en usuarios conectados a paneles fotovoltaicos. Red internacional de Investigadores en Competitividad, 13, 736-756.

DOF: 07/03/2017 RESOLUCIÓN de la Comisión Reguladora de Energía por la que expide las disposiciones administrativas de carácter general, los modelos de contrato, la metodología de cálculo de contraprestación y las especificaciones técnicas generales, aplicables a las centrales eléctricas de generación distribuida y generación limpia distribuida.

GEMIS. "Modelo de Emisiones Globales para Sistemas integrados". Consultado en https://ghgprotocol.org/Third-Party-

Databases/GEMIS

Global Energy Trade, reporte marzo-abril, (2020). Monitor de información comercial $e$ índice de Precios de Generación Solar Distribuida en México. https://www.worldenergytrade.com/energiasalternativas/general/generacion-distribuidapotencial-de-crecimiento

\section{INEGI}

http://www.beta.inegi.org.mx/app/areasgeografi cas/?ag=04.U.S. Department of Energy. National Renewable Energy Laboratory, (2010). https://maps.nrel.gov/rede-

mexico/?aL=wn05da\%255Bv\%255D\%3Dt\%26 u-o1v1\%255Bv\%255D\%3Dt\%26u-

o1v1\%255Bd\%255D\%3D1\%26mwBW5c\%25 5Bv\%255D\%3Dt\%26mwBW5c\%255Bd\%255 D\%3D2\%26mwBW5c\%255Br\%255D\%3Dt\%2 6tpot_result_mexico_145835\%255Bv\%255D\% 3Dt\%26tpot_result_mexico_145835\%255Bd\% 255D\%3D3\%26tpot_result_mexico_145835\%2 $55 \mathrm{Br} \% 255 \mathrm{D} \% 3 \mathrm{Dt} \& \mathrm{bL}=\mathrm{clight} \& \mathrm{cE}=0 \& \mathrm{R}=0 \&$ $\mathrm{mC}=21.861498734372567 \% 2 \mathrm{C}-$ $87.4951171875 \& z \mathrm{~L}=5$ 
León Llanos J. A. (2020). Generación distribuida mediante el diseño de un Sistema fotovoltaico conectado a la red de distribución en el Instituto ISA-Chiclayo.

Lezama Zárraga, F. R, Andrade Durán, J. E., Ovando Sierra, J. C. \& Castillo Téllez, M. Aplicación de Eficiencia Energética para optimizar el Sistema de Iluminación en una Institución de Nivel Superior. Revista de aplicaciones de la Ingeniería. ISSN 2523-6873. Edit. Ecorfan Bolivia, Vol. 2, No. 8, páginas 2734. 2018.

Luis C. A., A. R., \& María Beatriz, P. (2020). Proyectos fotovoltaicos en generación distribuida. ¿Rentabilidad Privada o Sustentabildad Ambiental? Revista politécnica, 45(2), 31-40.

Mayra Robles López et al. La eficiencia energética en microempresas mexicanas. https://www.uv.mx/iiesca/files/2017/03/19CA21 602.pdf

Merle Potter, David Wiggert, Bassem Ramadam, (2012). Mecánica de Fluidos $4^{a}$ edición. Editorial CENGAGE Learning, ISBN 13:978-607-519-450-9.

N.H. Reich, E.A. Alsema, W.G.J.H.M. van Sark, E. Nieuwlaar. " $\mathrm{CO}_{2}$ Emissions of $\mathrm{PV}$ in the perspective of a renewable energy economy". $22^{\text {nd }}$ European Photovoltaic Solar Energy Conference, pp. 3538-3542. Milan, Italy. September 2007.

Pinargote, D. F. G., Sornoza, G. J. B., Pérez, A. V., \& Gámez, M. R. (2021). La generación distribuida y su regulación en el ecuador. Brazilian Journal of Business, 3(3).

Ramos, E. (2020). La generación distribuida: el camino hacia la producción descentralizada de electricidad y pautas para su reglamentación. Forseti. Revista de derecho, 8(11), 07-35.

Rayenari D. C., J. Chan-González, Roger C., Jesús Contreras, M. Margarita Castillo-Téllez, Francisco Lezama, Víctor Lanz, J. Ortega (2015) Sistema fotovoltaico interconectado a red instalado en el estacionamiento de la Facultad de Ingeniería de la Universidad Autónoma de Campeche. Memorias del Congreso Nacional de Energía Solar.
Terol Calvo, S. (2020) El acceso de la energía distribuida en conjuntos residenciales. Evaluación de sistemas fotovoltaicos comunitarios en la villa olímpica (Doctoral dissertation).

Víctor Lanz Gutierrez de Velazco, Manuel Cervera, (2018) Auditorías Energéticas a las Instalaciones de la Universidad Autónoma de Campeche, Comunicado Personal.

Victorio Santiago Díaz, Raúl Oscar. (2005) Acondicionamiento termico de edificios/ Thermal Preparation of Buildings. Editorial NOBUKO, ISBN 987-1135-94-7.

Yunus Cengel, Afshin J. Ghajar, (2011) Transferencia de Calor y Masa $4^{a}$ edición. Editorial McGraw Hill, ISBN 978-607-15-05408. 